\title{
RISK MITIGATION AND SOVEREIGN GUARANTEES FOR PUBLIC-PRIVATE PARTNERSHIPS IN DEVELOPING ECONOMIES
}

Alexander N. Jett

NO. 564

November 2018
ADB ECONOMICS WORKING PAPER SERIES 


\section{Risk Mitigation and Sovereign Guarantees for Public-Private Partnerships in Developing Economies}

Alexander N. Jett

No. 564 | November 2018
Alexander N. Jett (ajett@adb.org) is a Senior PublicPrivate Partnership Specialist at the Office of PublicPrivate Partnership, Asian Development Bank.

This paper has been prepared as background material for the Asian Development Outlook 2017 Update theme chapter on Sustaining Development through Public-Private

Partnership. 
(C) 2018 Asian Development Bank

6 ADB Avenue, Mandaluyong City, 1550 Metro Manila, Philippines

Tel +632632 4444; Fax +6326362444

www.adb.org

Some rights reserved. Published in 2018.

ISSN 2313-6537 (print), 2313-6545 (electronic)

Publication Stock No. WPS189626-2

DOI: http://dx.doi.org/10.22617/WPS189626-2

The views expressed in this publication are those of the authors and do not necessarily reflect the views and policies of the Asian Development Bank (ADB) or its Board of Governors or the governments they represent.

ADB does not guarantee the accuracy of the data included in this publication and accepts no responsibility for any consequence of their use. The mention of specific companies or products of manufacturers does not imply that they are endorsed or recommended by ADB in preference to others of a similar nature that are not mentioned.

By making any designation of or reference to a particular territory or geographic area, or by using the term "country" in this document, ADB does not intend to make any judgments as to the legal or other status of any territory or area.

This work is available under the Creative Commons Attribution 3.0 IGO license (CC BY 3.0 IGO)

https://creativecommons.org/licenses/by/3.o/igo/. By using the content of this publication, you agree to be bound by the terms of this license. For attribution, translations, adaptations, and permissions, please read the provisions and terms of use at https://www.adb.org/terms-use\#openaccess.

This CC license does not apply to non-ADB copyright materials in this publication. If the material is attributed to another source, please contact the copyright owner or publisher of that source for permission to reproduce it. ADB cannot be held liable for any claims that arise as a result of your use of the material.

Please contact pubsmarketing@adb.org if you have questions or comments with respect to content, or if you wish to obtain copyright permission for your intended use that does not fall within these terms, or for permission to use the ADB logo.

Notes:

In this publication, "\$” refers to United States dollars.

Corrigenda to ADB publications may be found at http://www.adb.org/publications/corrigenda. 


\section{CONTENTS}

TABLES AND FIGURES

ABSTRACT

$\begin{array}{lll}\text { I. INTRODUCTION } & 1\end{array}$

II. RISKS IN INVESTING IN INFRASTRUCTURE PUBLIC-PRIVATE PARTNERSHIPS 2

III. GOVERNMENT SUPPORT TO REDUCE RISK IN INFRASTRUCTURE

PUBLIC-PRIVATE PARTNERSHIPS

IV. THE ROLE OF MULTILATERAL DEVELOPMENT BANKS IN SOVEREIGN RISK MITIGATION 7

A. Case Study: Making a Kenya Power Project Viable Using Partial Risk Guarantees 9

B. Case Study: How a Turkish Hospital Public-Private Partnership Broke the Sovereign Ceiling

V. ESTIMATING THE BENEFITS OF A MULTILATERAL DEVELOPMENT BANK PARTIAL RISK GUARANTEE

VI. CONCLUSION AND POLICYIMPLICATIONS

APPENDIX: ANALYTICAL FRAMEWORK 


\section{TABLES AND FIGURES}

\section{TABLES}

1 ADB Survey Results on Infrastructure Investor Risk Perceptions in Asia 2

2 Regression Analysis on the Effect of Country and Sovereign Risk Ratings to the Number of Financially Closed Infrastructure Public-Private Partnership $\quad 5$

3 Guarantee Options for Government Payment Obligations

\section{FIGURES}

$1 \quad$ Risk Profile of ADB's 39 Borrowing Member Countries 3

2 Modalities for Allocating Demand Risk in Public-Private Partnership Projects 6

3 Sovereign Partial Risk Guarantee Using a Letter of Credit for a Public-Private Partnership 8

$4 \quad$ Partial Risk Guarantee Structure for Thika Power 10

$5 \quad$ Government Annuity Payments with and without Multilateral Development Bank Sovereign Partial Risk Guarantees

6 Estimated Financial Benefits of a Sovereign Partial Risk Guarantee 13

7 Estimated Financial Benefits of a Nonsovereign Partial Risk Guarantee 14 


\begin{abstract}
Public-private partnerships (PPPs) face a range of challenges in developed economies, such as appropriate risk sharing, attracting the right sponsors, and ensuring quality of service. As a large percentage of ADB's developing member countries are considered risky borrowers by international standards, sovereign risks play an important role in predicting the number of PPPs as well as the size of investment commitments. To catalyze PPPs in developing economies with higher risk ratings, sovereign risk mitigation is often needed. This article explores how country and sovereign risks deter private investors, solutions provided by multilateral development banks to reduce these risks, and policy implications for employing these solutions.
\end{abstract}

Keywords: public-private partnership, risk mitigation, sovereign guarantees

JEL codes: G32, H41, H81 


\section{INTRODUCTION}

What hinders private sector investment in infrastructure projects-and what measures are available to overcome these obstacles-have important implications for setting public-private partnership (PPP) policies. Financing infrastructure involves a wide array of risks, the severity of which varies by specific project conditions. The presence of these risks may deter private sector investment in infrastructure. At the core of the PPP procurement model is the concept that PPP contracts allocate risks to the party most capable of managing them (IISD 2015). This functional feature of PPPs is a prerequisite to the increased involvement of the private sector in the delivery of infrastructure services. A major reason why there are relatively few infrastructure PPPs in developing Asia is that many governments do not have the confidence of the private sector that that they will fulfill their contractual obligations. So, simply restructuring projects to shift more risks to the government may still fail to attract investors.

The two main measures of risk in an investment environment for sovereign entities are country and sovereign risks. These closely related concepts are prevalent in most countries in developing Asia and can deter the development of PPPs by making projects less financially viable. The Organisation for Economic Co-operation and Development (OECD) assesses country risk based on three general risk indicators: the payment experience of the participants and a country's financial and economic situation. Standard \& Poor's (S\&P) sovereign risk, however, refers to the capacity and willingness of a government to service its debt in accordance with the agreed terms. Country risk is broader because it incorporates credit risk exposures from other creditors within a country. Countries considered high risk by the OECD and S\&P measures need some form of guarantee or additional government support to backstop their sovereign obligations. Based on these measures, a large percentage of the borrowing member countries of the Asian Development Bank (ADB) are classified as risky.

To mitigate these risks, tools are available that can promote the use of PPPs and make infrastructure projects attractive to private investors. Traditionally, this has been done through financial and legal transaction structuring and applying risk allocation, but governments in riskier countries should go further by providing sovereign guarantees or government support agreements. And if these do not gain investor confidence, then multilateral development banks (MDBs) can play an important role by offering risk mitigation tools such as credit enhancement products.

This paper examines country and sovereign risks in infrastructure PPP financing, and the complementary roles of governments and MDBs in mitigating these risks. Through surveys, a literature review and our own statistical analysis, we identify the main risks for PPP investors and analyze the effect of country risk and risk mitigation measures on the probability of PPP projects successfully reaching financial close. The paper suggests MDB-issued guarantees such as letters of credit and partial risk guarantees are beneficial to PPP investment and can reduce sovereign risk of a country. The involvement of MDBs should not be limited to downstream PPP investment but also to upstream support through technical assistance or capacity building.

The paper is structured as follows. Section II presents the risks in investing in infrastructure public-private partnerships. Section III discusses how government support can reduce the risks associated with infrastructure investment. Section IV looks into the role of MDBs in sovereign risk mitigation. Section $\vee$ presents the potential financial benefits of an MDB's partial risk guarantee using 
shadow bid financial model. ${ }^{1}$ Finally, the paper closes by describing implications for policy makers interested in employing the structures and instruments described to reduce the perceived risks of government counterparties and encourage more investment.

\section{RISKS IN INVESTING IN INFRASTRUCTURE PUBLIC-PRIVATE PARTNERSHIPS}

Table 1 shows the results of a 2015 survey by ADB's Independent Evaluation Department of infrastructure investors in Asia ranking their risk perceptions (IED 2017). ${ }^{2}$ Most of the responses were from guarantors including: export credit agencies, export-import banks, MDBs, bilateral development banks, specialized multilateral insurers, and private insurers. These institutions may be overrepresented in the sample while project sponsors and equipment providers may be underrepresented.

Table 1: ADB Survey Results on Infrastructure Investor Risk Perceptions in Asia

\begin{tabular}{ll}
\hline Risk & $\begin{array}{c}\text { Percentage of Respondents } \\
\text { Indicating That the Risk is High }\end{array}$ \\
\hline Payment risk on subsovereign borrowers/guarantors & 68 \\
Breach of contract & 67 \\
Payment risk on sovereign borrowers/guarantors & 62 \\
Country or political risks & 59
\end{tabular}

$\mathrm{ADB}=$ Asian Development Bank.

Note: The survey participants were asked what they thought were the most important risks or challenges in financing or investing in infrastructure projects in Asia.

Source: Independent Evaluation Department (IED). 2017. Boosting ADB's Mobilization Capacity: The Role of Credit Enhancement Products. Manila: ADB.

The top three risks in Table 1 refer to governments, at the sovereign or subsovereign level, failing to meet their contractual obligations, especially their payment obligations. The top risk refers specifically to subsovereign borrowers. Since PPPs generally contain either direct payment obligations from governments, such as availability payments or contingent payment obligations, a negative perception of payment risk from government would be an obvious deterrent to private investors. The fourth risk more broadly states country or political risks, such as war, expropriation, civil disturbance, and breach of contract. In sum, the four highest risks relate to the sovereign counterparty in a PPP contract as opposed to commercial risks.

\footnotetext{
A shadow bid model is a financial model used before bidding. It estimates all project costs, including the cost of financing, and it can be used by advisors to governments to establish benchmarks.

2 The survey polled 183 institutions and received 78 responses. Institutions included guarantors (39 respondents), commercial banks (15 respondents), financial services organizations (15 respondents), and project sponsors and equipment suppliers ( 9 respondents). The questionnaires were sent to the institutions on 3 December 2015; the survey ended 29 February 2016.
} 
Figure 1: Risk Profile of ADB's 39 Borrowing Member Countries

(a) Country risk (OECD)

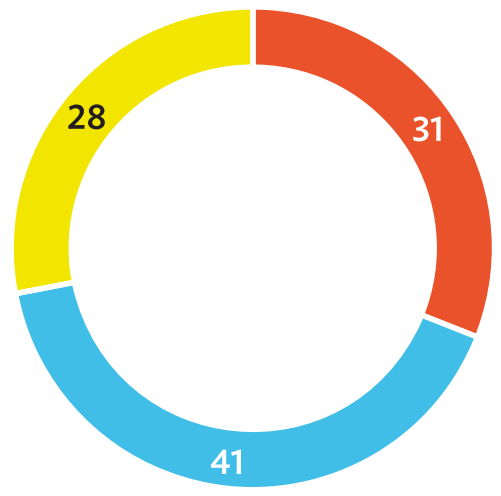

Unrated (risky)

Category 6 or 7 (highest risk)

Category 1-5 (b) Sovereign risk (S\&P)

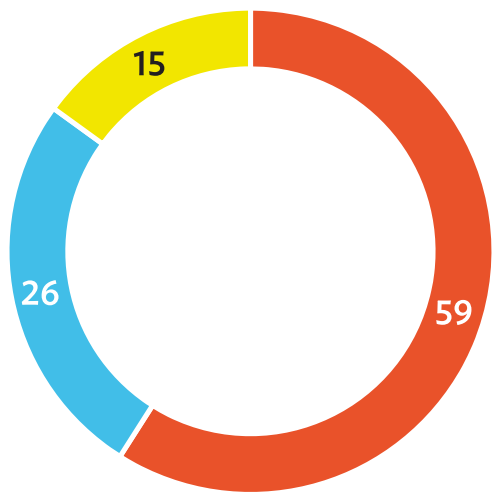

Unrated (not investment grade)

Below investment grade (BBB-)

At or above investment grade

OECD = Organisation for Economic Co-operation and Development, S\&P = Standard \& Poor's.

Note: Excluded Brunei Darussalam; Hong Kong, China; Malaysia, the Republic of Korea; Singapore; and Taipei,China.

Sources: OECD country risk classifications and S\&P global ratings.

Figure 1 shows that $41 \%$ of ADB's 39 borrowing member countries are in the highest risk category based on the OECD's country risk classification (that is, categories 6 and 7). ${ }^{3}$ Considered equally risky are the $31 \%$ of countries that do not have an investment grade credit rating. The OECD's rating categories recommend minimum risk premiums for export credits, including guarantees. $A$ higher risk category rating may ultimately translate into a higher interest rate, which reduces the financial viability of PPPs. A proxy for the interest rate can be derived directly from the risk premium charged by export credit agencies, which is based on this classification. More importantly, many banks will not lend to category 6 or 7 countries or, if they do, will either apply special scrutiny or only lend to PPPs that have hard currency revenues, such as oil wells and international airports.

Using the S\&P's sovereign risk definition even more ADB borrowing developing member countries (DMCs) are considered risky (Standard \& Poor's Global Ratings 2017). In 2015, 26\% of ADB's borrowing DMCs were below investment grade (BBB-), while 59\% were unrated and would therefore be considered risky by international lenders. S\&P measures sovereign creditworthiness by scoring five key areas: institutional (how a government's institutions and policy making affect a sovereign's credit fundamentals); economic (economic diversity and volatility, income levels, and growth prospects); external (external liquidity and international investment position); fiscal (fiscal performance and flexibility, and debt burden); and monetary (a monetary authority's ability to fulfill its mandate while sustaining a balanced economy and attenuating any major economic or financial shocks).

3 ADB's country risk assessment model also gives qualitative assessments of countries' political risk on a scale of 1 (lowest) to 7 (highest). 
There is evidence that macroeconomic factors affect the bankability of PPP projects. Hammami, Ruhashyankiko, and Yehoue (2006), using the World Bank's Private Participation in Infrastructure Database, conclude that macroeconomic stability achieved through price stability, together with conducive market conditions, are associated with more projects being committed. A survey on the implementation of PPP infrastructure projects in Nigeria found that poor project bankability; unstable economic policies; and weak financial, technical, and managerial capabilities of concessionaires were the main factors preventing projects from reaching financial close (Babatunde and Perera 2016).

Reducing risk profiles and having higher credit ratings can attract private investment since these drive investment decisions. Sovereign and country risks play an important role in predicting the number of PPPs reaching financial close and the size of private investments. In their empirical analysis using Euromoney's measure of country risk, Araya, Schwartz, and Andrés (2013) find that private sector participation in infrastructure projects is sensitive to country risk; that is, risk ratings are a generally reliable predictor of PPP investments in developing countries. An improvement in country risk scores has a positive effect, from $21 \%$ to $41 \%$, on the probability of having PPP commitments as well as investments in dollar terms. ${ }^{4}$ Interestingly, the authors find the result consistent with all infrastructure sectors.

Using both OECD measures of country risk and S\&P's definition of sovereign risk as independent variables, a regression analysis that uses the same methodology (see Appendix) finds similar results to Araya, Schwartz, and Andrés (2013) (Table 2). Countries with higher country risk and lower S\&P ratings can adversely affect the number of infrastructure PPPs reaching financial close (models 1 and 2). When macroeconomic indicators are introduced (models 3 and 4), the S\&P rating loses significance. This result is intuitive since the rating is largely based on macroeconomic indicators.

Another major finding of the regression analysis is that the involvement of MDBs-through credit enhancement, for example-can significantly increase the number of projects reaching financial close (models 5 and 6 ). PPPs are assessed on a project by project basis and can therefore still be viable even though country risks are high, although they have a lower probability of being implemented.

4 Euromoney's country risk index is the weighted average of the following indicators: political risk (25\%), economic performance (25\%), debt indicators (10\%), debt in default or rescheduled (10\%), credit ratings (10\%), access to bank finance (5\%), access to short-term finance (5\%), access to capital markets (5\%), and discount on forfeiting (5\%). 
Table 2: Regression Analysis on the Effect of Country and Sovereign Risk Ratings to the Number of Financially Closed Infrastructure Public-Private Partnership

\begin{tabular}{|c|c|c|c|c|c|c|}
\hline Explanatory variables & Model 1 & Model 2 & Model 3 & Model 4 & Model 5 & Model 6 \\
\hline OECD country risk & $\begin{array}{l}-0.442^{* * *} \\
(0.087)\end{array}$ & & $\begin{array}{l}-0.548^{* * *} \\
(0.212)\end{array}$ & & $\begin{array}{l}-0.580^{* * *} \\
(0.172)\end{array}$ & \\
\hline S\&P rating & & $\begin{array}{l}-1.171^{*} \\
(0.670)\end{array}$ & & $\begin{array}{c}-0.772 \\
(0.912)\end{array}$ & & $\begin{array}{l}-1.262 \\
(0.878)\end{array}$ \\
\hline GDP growth & & & $\begin{array}{l}0.034^{* * *} \\
(0.013)\end{array}$ & $\begin{array}{l}0.034^{* * *} \\
(0.013)\end{array}$ & $\begin{array}{l}0.029^{* * *} \\
(0.011)\end{array}$ & $\begin{array}{l}0.03^{* * *} \\
(0.011)\end{array}$ \\
\hline Inflation & & & $\begin{array}{l}-0.088 \\
(0.054)\end{array}$ & $\begin{array}{c}-0.088^{*} \\
(0.053)\end{array}$ & $\begin{array}{c}-0.067 \\
(0.049)\end{array}$ & $\begin{array}{c}-0.078^{*} \\
(0.046)\end{array}$ \\
\hline Openness & & & $\begin{array}{c}1.227^{*} \\
(0.726)\end{array}$ & $\begin{array}{c}1.293^{* *} \\
(0.560)\end{array}$ & $\begin{array}{c}1.241^{*} \\
(0.691)\end{array}$ & $\begin{array}{l}1.203^{* *} \\
(0.539)\end{array}$ \\
\hline $\begin{array}{l}\text { OECD's country risk and } \\
\text { MDB's PPP participation }\end{array}$ & & & & & $\begin{array}{l}0.127^{* * *} \\
(0.024)\end{array}$ & \\
\hline $\begin{array}{l}\text { S\&P ratings and MDB's PPP } \\
\text { participation }\end{array}$ & & & & & & $\begin{array}{l}0.629^{* * *} \\
(0.101)\end{array}$ \\
\hline /Inalpha & $\begin{array}{r}-0.654 \\
(5.814)\end{array}$ & $\begin{array}{c}-0.156 \\
(5.624)\end{array}$ & $\begin{array}{c}0.283 \\
(6.593)\end{array}$ & $\begin{array}{c}0.606 \\
(5.269)\end{array}$ & $\begin{array}{c}0.181 \\
(6.263)\end{array}$ & $\begin{array}{c}0.474 \\
(5.254)\end{array}$ \\
\hline Constant project & $\begin{array}{l}3.401^{* * *} \\
(0.455)\end{array}$ & $\begin{array}{l}2.489^{* * *} \\
(0.639)\end{array}$ & $\begin{array}{c}-0.341 \\
(1.451)\end{array}$ & $\begin{array}{l}-2.298 \\
(2.212)\end{array}$ & $\begin{array}{r}-0.739 \\
(1.513)\end{array}$ & $\begin{array}{l}-1.963 \\
(2.053)\end{array}$ \\
\hline Observations & 964 & 800 & 892 & 762 & 892 & 762 \\
\hline Number of country & 107 & 66 & 98 & 64 & 98 & 64 \\
\hline
\end{tabular}

$\mathrm{GDP}=$ gross domestic product, $\mathrm{MDB}=$ multilateral development bank, $\mathrm{OECD}=$ Organisation for Economic Co-operation and Development, PPP = public-private partnership, S\&P = Standard \& Poor's.

Notes: Standard errors in parentheses. OECD country risk: 1 if a country has lowest risk and 7 if highest. S\&P rating: 1 if a country is below investment grade (BBB-) or unrated and 0 otherwise. ${ }^{* *} p<0.01^{* *} p<0.05^{*} p<0.1$.

Source: Author and Mai Lin Villaruel.

\section{GOVERNMENT SUPPORT TO REDUCE RISK IN INFRASTRUCTURE PUBLIC-PRIVATE PARTNERSHIPS}

Even though investors face high risks with infrastructure PPP projects in developing countries, measures can be taken to reduce and share these risks. Risk allocation is a vital element in structuring PPP projects in developed and developing countries. The literature suggests that risks should be allocated to the party best able to affect the risk factor, influence the sensitivity of a project to the risk, and absorb the risk (Irwin 2007).

Because of the high risk, governments offer many forms of support for PPPs in Asia (Figure 2). The most common are land acquisition and resettlement costs, minimum demand and revenue guarantees, payment obligation guarantees, currency inconvertibility and transferability risk guarantees, and credit guarantees. Other forms of support include viability gap funding and grant funding at financial close to be used during construction (though this is usually limited to a percentage of a project's capital cost and given on a case-to-case basis). Figure 2 shows the modalities for allocating demand risk in PPP projects with the highest risks for the private investor at the top of the 
chart. For investors, there is generally a direct relationship between risk and return. The figure gives a conceptual relationship between demand risk and the cost of capital with availability or capacity payments allocating the least amount of risk to private investors and full demand risk for greenfield projects without reliable data have the highest amount of risk for investors.

Figure 2: Modalities for Allocating Demand Risk in Public-Private Partnership Projects

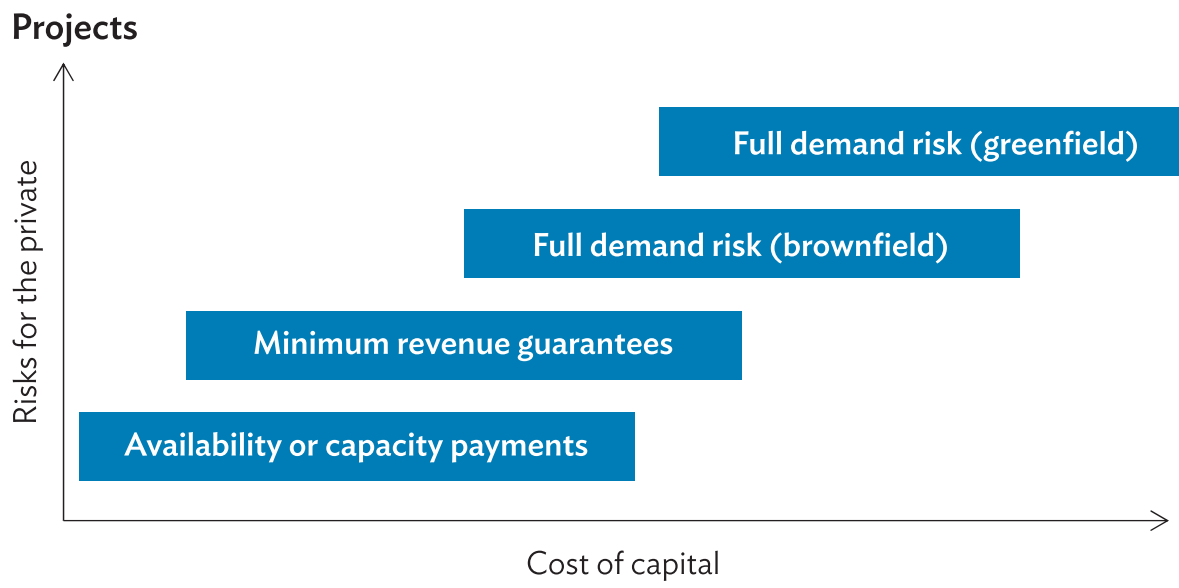

Source: Author.

Typically, one would expect projects to have a lower cost of capital when risks are reduced through government commitments to mitigate them through minimum revenue guarantees or availability payments. This lower cost of capital should translate into lower project costs and ultimately benefit the government. This is generally the case, but these commitments are only as good as the level of adherence to them by the government counterparty handling the PPP. As Irwin (2007) put it, the government counterparty must be able to absorb the risk. The government counterparty could be a state-owned utility or bulk power supplier for a power PPP, a municipal utility for a water PPP, and a government contracting agency for a transport PPP.

Governments can improve the domestic investment climate by fostering greater transparency; combating corruption, particularly at the sector level; and improving investor and creditor rights and protection. Doing this can significantly reduce economic and political risks that would otherwise result in extremely high risk premiums (Schwartz, Ruiz-Nuñez, and Chelsky 2014). In the absence of improving the domestic investment climate, governments can offer explicit guarantees or performance undertakings. In Bangladesh, for example, the allocation of risk in power PPPs is designed to deal with skepticism in the private sector over creditworthiness and the ability of government counterparties to meet payments. Many power infrastructure projects in Bangladesh that reached financial close relied on the government recognizing the payment obligations of government counterparties as sovereign obligations in the project agreements (ADB 2017).

Private investors, however, are sometimes unwilling to accept sovereign guarantees or similar support mechanisms because of poor credit ratings or high country risk profiles. In the "weakest link" credit model used by many project finance rating methodologies, the sovereign rating is a ceiling beyond which the project cannot be rated, except with special justification. S\&P, for example, states this in its methodology for project finance transactions. 


\section{THE ROLE OF MULTILATERAL DEVELOPMENT BANKS IN SOVEREIGN RISK MITIGATION}

Substantial debt financing is available for infrastructure projects in countries with investment grade credit ratings, but there is not much investor appetite for PPPs in countries below investment grade and in emerging markets generally. Credit support for infrastructure PPP projects can be used to mitigate sovereign, macroeconomic, and project-specific risks, which could benefit PPP projects with weak credit profiles (OECD 2017).

Because a government's sovereign guarantees may not be enough to make projects financially viable, MDBs can be catalysts for investment. As our regression analysis indicates, there is empirical evidence to support the role of MDBs in providing credit enhancement. Credit enhancement products offered by MDBs can be an efficient, targeted form of intervention. They can lower risks to investment opportunities in difficult sovereign environments so that projects become attractive for risk-averse investors and crowd in private capital to finance infrastructure in developing countries (Moody's Investors Service 2017). Many credit enhancement tools are already available in the market as well as through international financial institutions. ADB (2017) identified comprehensive guarantees covering commercial and political risks as the most important form of credit guarantee (high importance), followed by extended political risk guarantees.

The private sector operations of MDBs offer guarantees, syndication, and risk transfers for private insurers. These cover many risks, including political risk and breach of contract for government payments or reimbursement to lenders in case a project is terminated. These products are typically marketed to sponsors with lenders as the ultimate beneficiary. Private investors see significant value as well as an untapped demand for using these products, especially in lower-income countries trying to increase private participation in infrastructure (Moody's Investors Service 2017). This implies that they could be used more often.

Table 3: Guarantee Options for Government Payment Obligations

\begin{tabular}{|c|c|c|c|c|}
\hline & $\begin{array}{l}\text { World Bank } \\
\text { IDA PRG }\end{array}$ & $\begin{array}{l}\text { ADB Sovereign } \\
\text { PRG/PCG }\end{array}$ & $\begin{array}{l}\text { MIGA Breach } \\
\text { of Contract }\end{array}$ & $A D B$ \\
\hline Guarantee fee & 75 bps & $50 \mathrm{bps}$ & Market & Market \\
\hline Commitment fee & 0 bps & $15 \mathrm{bps}$ & & \\
\hline MOF requirement & Counter indemnity & Counter indemnity & None & None \\
\hline Arbitration & None & None & Yes & Yes \\
\hline Credit rating of guarantor & AAA & AAA & Shadow rated & AAA \\
\hline Ultimate beneficiary & Sponsors and lenders ${ }^{\mathrm{a}}$ & Sponsors and lenders ${ }^{\mathrm{a}}$ & Sponsors and lenders & Lenders \\
\hline
\end{tabular}

$\ldots=$ not available, $\mathrm{ADB}=$ Asian Development Bank, bps = basis points, IDA = International Development Association, $\mathrm{MIGA}=$ Multilateral Investment Guarantee Agency, MOF = ministry of finance, PCG = Partial credit guarantee, PRG = partial risk guarantee.

Note: An obligor rated AAA has extremely strong capacity to meet financial commitments. AAA is the highest issuer credit rating assigned by Standard \& Poor's.

a Through a letter of credit, the beneficiary would technically be the issuing bank.

Sources: Author; Asian Development Bank (ADB). 2011. Guarantees against Political Risks. Manila; and World Bank. Guarantees Program. http://www.worldbank.org/en/programs/guarantees-program\#5.

Sovereign partial risk guarantees are another tool that MDBs can use to tackle country risk. These guarantees disburse funds according to preestablished triggers that are legally binding on both the grantor (typically a state-owned enterprise or government agency) and the concessionaire (PPP project company). They also require a sovereign counter indemnity from the government, which 
defines the government's obligation as well as the penalties that MDBs can apply for noncompliance. Table 3 compares guarantee products from the World Bank Group and ADB that can be used to backstop government payment obligations in a PPP contract and describes the pricing of the products (if published) as well as the main beneficiaries. These products were developed by MDBs to cover a wider range of risks than those typically used by the private insurance market, particularly government default on their contractual obligations. In this sense, sovereign partial risk guarantees cover an area between traditional political risk and commercial risk, though they are not a form of political risk insurance (Matsukawa and Habeck 2007). Figure 3 outlines the triggering mechanism for sovereign partial risk guarantees with a letter of credit.

Figure 3: Sovereign Partial Risk Guarantee Using a Letter of Credit for a Public-Private Partnership

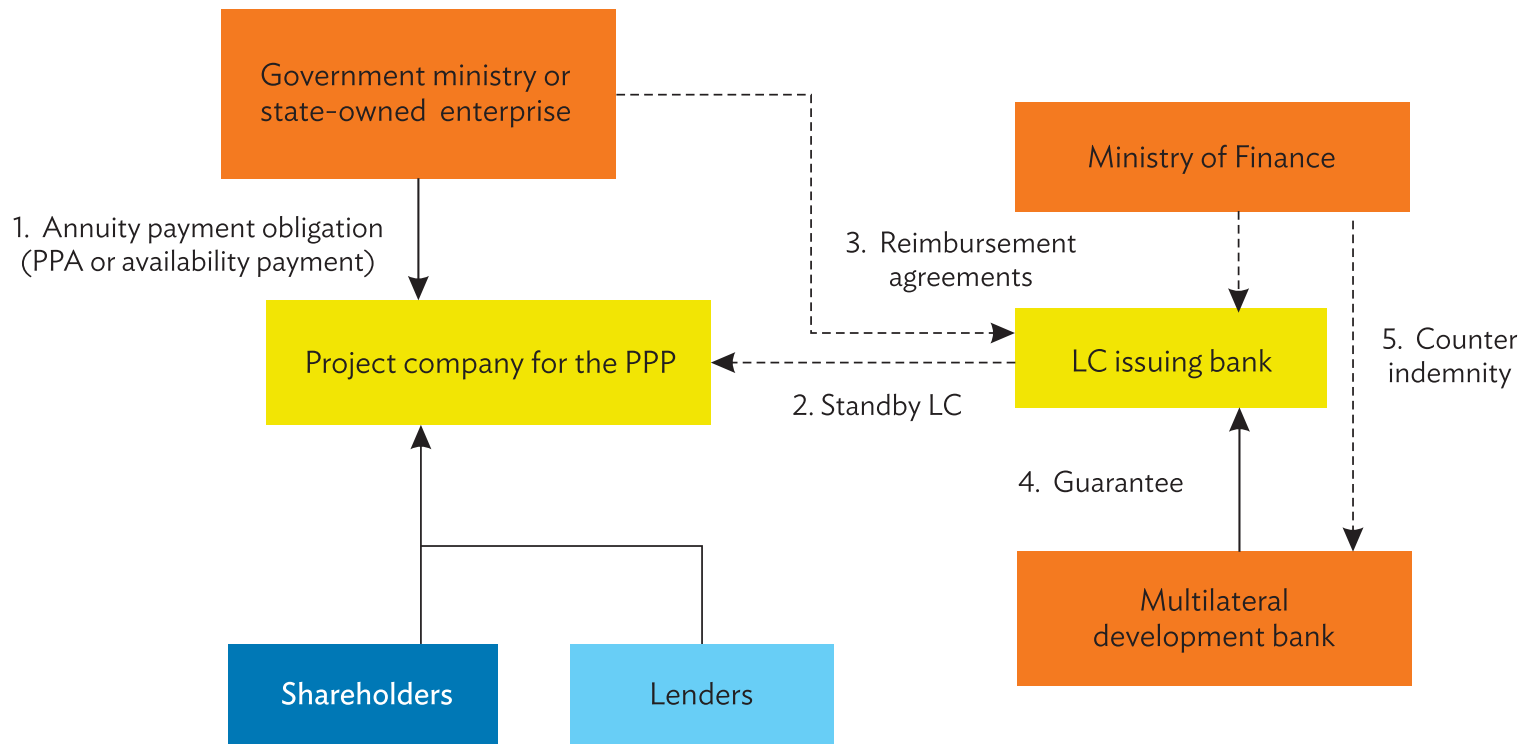

LC = letter of credit, PPA = power purchase agreement, $\mathrm{PPP}=$ public-private partnership.

Note: A default in the payment obligation of the government or state-owned enterprise will result in the on-demand payment of the LC and the LC issuing bank will then seek reimbursement. The guarantee is called if the reimbursement is not paid within the reimbursement period. The counter indemnity is then called if it is not reimbursed within a period specified by the multilateral development bank, for example 90 days.

Source: Author.

Sovereign partial risk guarantees have two main advantages over traditional insurance. The first is pricing. The sovereign counter indemnity and guarantee agreement ensures that projects can be priced at a similar interest rate to sovereign loans offered by MDBs. The second is timing. In traditional political risk insurance, the sponsor needs to have an arbitral award to receive payment. A sovereign partial risk guarantee with a letter of credit has the advantage of paying out automatically based on preestablished triggers defined in the PPP contract. These triggers can be linked to key performance indicators that are verified by an independent engineer, whose verification is legally binding on both the government and private partner. 


\section{A. Case Study: Making a Kenya Power Project Viable Using Partial Risk Guarantees}

The following looks briefly how a sovereign partial risk guarantee was used for a PPP power project in Kenya. Kenya Power (previously Kenya Power and Lighting Company) is a professionally managed power utility, majority owned by the Government of Kenya and traded on the Nairobi Security Exchange. After the 2008 global financial crisis, Kenya Power found it difficult to attract investors for power projects - a situation aggravated by the political unrest after the 2007 elections.

Despite this difficult operating environment, the company steadily improved its performance and by 2010 had several power purchase agreements with independent power producers. But because of droughts from 2009 to 2011, it did not have enough energy from its hydropower plants and had to contract emergency generation at a very high price- $\$ 0.321$ per kilowatt-hour.

Having to use emergency generation was a heavy financial burden on Kenya Power, which decided to contract new thermal and geothermal generation capacity to reduce the reliance on emergency generation in the medium term. It earmarked four independent power producers to provide a solution to Kenya Power's power shortage (Kaçaniku and Izaguirre-Bradley 2015). Kenya's Thika Power Ltd. was one such provider and was slated to design, build, operate, and maintain an 87-megawatt combined cycle diesel plant. Revenue for Thika was to come from a 20-year power purchase agreement with Kenya Power, the government counterparty for the power purchase agreement.

Because Kenya Power faced a cash shortage, and because of the recent political unrest, the Thika power project would not have been viable without credit enhancement from MDBs. The World Bank Group, including the Multilateral Investment Guarantee Agency (MIGA) and the International Development Association (IDA) provided a credit enhancement package to bolster financing for Thika Power and the other three projects.

For credit enhancement, MIGA provided political risk insurance to cover termination payments for commercial lenders and sponsor equity, and IDA provided the partial risk guarantee with a letter of credit to cover Kenya Power's payment obligations under the power purchase agreement (Figure 4).

MIGA's political risk insurance was intended to cover commercial lenders in case of termination and protect sponsors from political risk events and had a term of 15 years to encourage longer-term lending. The IDA's partial risk guarantee covered payment risk from Kenya Power. The letter of credit covered 3 months of capacity and energy payments and 2 months of fuel payments and was offered on a rolling basis. It would pay out automatically whether the payment was missed due to Kenya Power's default or government interference. The letter of credit would also pay if there was a force majeure event preventing Kenya Power from meeting its obligations. The company had 12 months to repay the letter-of-credit issuing bank before the guarantee was called. This mechanism ensured continuity for the 15-year period of support.

Thika Power, along with the other independent power producers receiving IDA's partial credit guarantees were the first in Kenya to attract long-term commercial financing. Of the total $\$ 623$ million funding for the four projects, $\$ 181$ million was provided by commercial banks. For Thika Power, MIGA insured up to $€ 81$ million ( $\$ 94$ million). This supported local investors and added 298 megawatts of generation capacity that was critically needed in Kenya. 


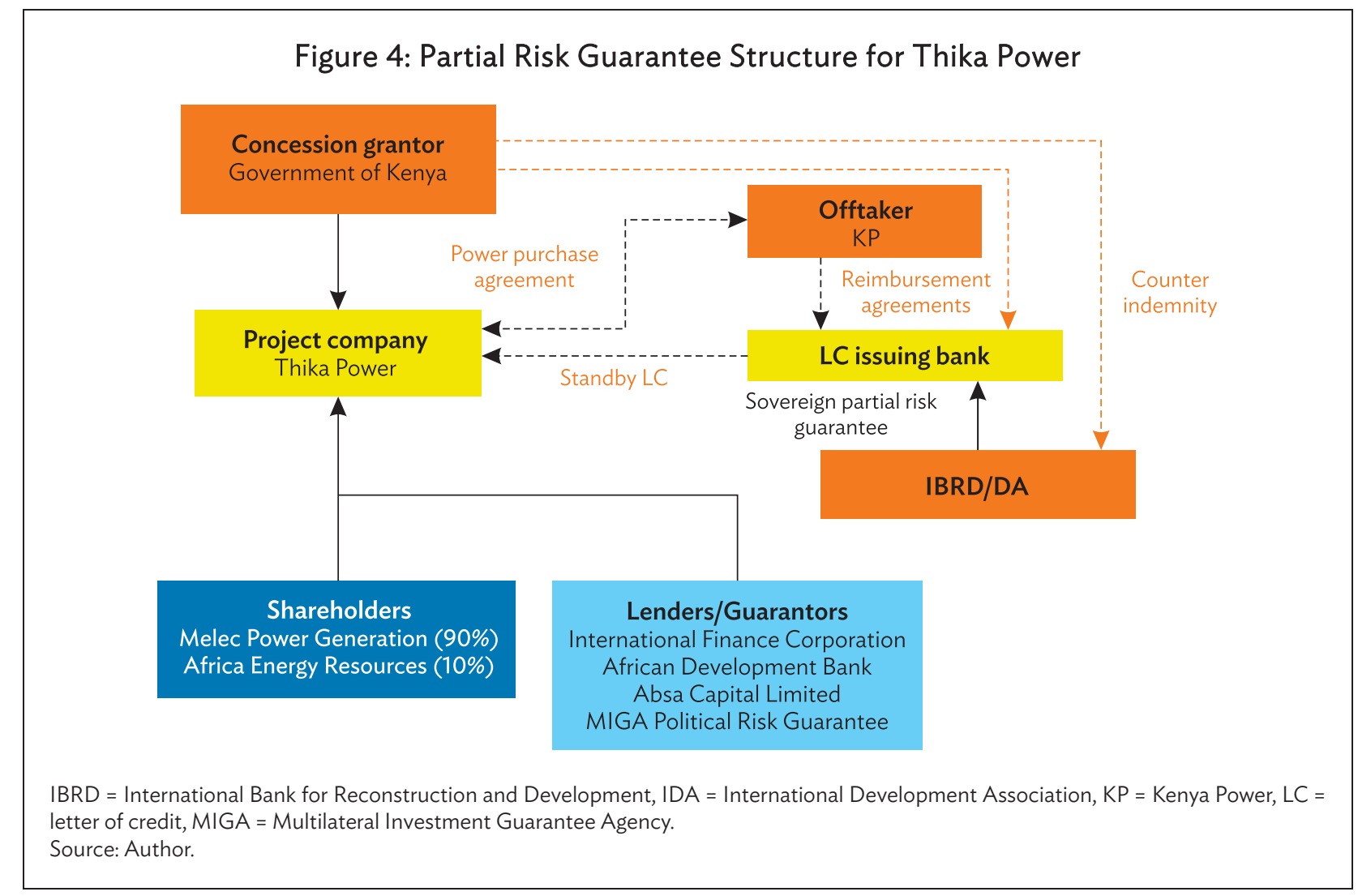

An important factor for the success of this transaction lays in the two types of support provided by the multilateral agencies to the projects - that is, MIGA covered termination payment and IDA's partial risk guarantee through the letter of credit provided covered power purchase agreement payments and, through its triggering mechanism, ensured timely payments. Payment was due on demand based on the verification process in the contract and did not need an arbitral award from an international court of law (Government of Kenya and International Development Association 2012).

Another success factor was that the guarantee cover reduced the government's contingent liabilities. If the IDA's partial risk guarantee cover had not been given, the government would have had to provide an explicit sovereign guarantee to cover all of Kenya Power's obligations for the duration of the power purchase agreement. The alternative would have been for Kenya Power to provide its own cash collateral, which would have further strained its finances. Both options would have cost much more than the $\$ 35$ million and $€ 7.7$ million ( $\$ 9.1$ million) in the letters of credit.

The Kenya Power Project demonstrates several advantages of a sovereign partial risk guarantee that helped catalyze $\$ 623$ million for four independent power producers in Kenya. A disadvantage of this product is that a counter indemnity may be hard to obtain from governments, who, possibly along with private sponsors, may not be aware of the advantages of sovereign guarantees, making capacity building necessary. Outside of this product, other solutions are available to deal with sovereign counterparty risk in PPP transactions. 


\section{B. Case Study: How a Turkish Hospital Public-Private Partnership Broke the Sovereign Ceiling}

Another PPP project-Turkey's Elaziğ Hospital-describes how two different instruments were used to tackle the ability and willingness to pay of government counterparties. Elaziğ Hospital is a 1,038-bed complex comprising two hospitals and one clinic (Moody's Investors Service 2016). The project site was delivered in October 2016 and construction was expected to have been completed in September 2018). The total amount of the bond issuance to fund the hospital was $€ 282$ million ( $\$ 335$ million).

Project revenues consist of availability payments paid by the Ministry of Health for services provided by the project company, ProjectCo. To finance the project, two types of bonds rated by Moody's Investors Service were used: A1 bonds, which are credit enhanced; and A2 bonds, which are not.

The bonds benefited from two types of risk mitigation: extended political risk insurance coverage from the World Bank Group's MIGA, which includes classic coverage (transfer restriction and expropriation) and breach of contract. And a subordinated liquidity facility from the European Bank for Reconstruction and Development (EBRD), which protects ProjectCo in case of a breach of contract by the Ministry of Health.

Because of the level of risk mitigation provided by MDBs, this project was rated Baa2; that is, above Turkey's sovereign ceiling of Ba1. This is unusual in PPP projects generally, and it is even more unusual in social sector PPPs. Historically, ratings above the sovereign occur in mineral or oil extraction, which tend to have the characteristics-insulation and offshore, hard currency revenueneeded for a higher rating.

A major factor for this PPP's success was the credit enhancement provided by the MIGA and the EBRD. These institutions had the advantage of providing credit enhancement that was not affected by Turkey's sovereign environment. To break through a sovereign ceiling, a project must have better credit fundamentals than the sovereign and be insulated from domestic macroeconomic and financial disruptions.

Multilateral support for Turkey's health sector was also a factor for the higher ratings. This implies that upstream loans and technical assistance have a material impact on the bankability of PPPs.

It should be noted that the European Investment Bank uses a similar mechanism to the liquidity facility used by EBRD in this project, including an unfunded letter of credit that can cover up to $20 \%$ of the project cost during either the construction or operation phases. This facility can also raise projects below investment grade to investment grade (EIB 2012).

\section{ESTIMATING THE BENEFITS OF A MULTILATERAL DEVELOPMENT BANK PARTIAL RISK GUARANTEE}

Large infrastructure projects are even more costly once risk adjusted, while guarantees and complementary support from MDBs also increase PPP project costs by charging fees. The question is how to keep these costs as low as possible to reduce the cost of risk-adjusted PPP projects. Using a shadow bid financial model, this section presents the potential financial benefits, especially to the government, of a partial risk guarantee that MDBs provide. The model involves developing a shadow bid that provides an estimate of the annual service payments-the amount of revenue to cover all 
expected costs and provide the private partner with an attractive return-that the private sector would need to estimate before investing in a PPP project.

In a PPP project relying on government payments, the financial benefit to the government of using an MDB partial risk guarantee comes from a reduction in debt costs, enabling the project to raise financing at more favorable terms. The benefit will vary with the involvement of a sovereign counter indemnity by the host country. The sovereign country indemnity governs the repayment obligations in case the guarantee is called, and it allows the guarantee to be governed under similar conditions to sovereign loans with cross-default and cross-acceleration provisions. It also reduces the pricing of the guarantee when compared with private insurance markets.

Below is an example of how an MDB partial risk guarantee can reduce the total cost to the government. In this scenario, the infrastructure PPP project's shadow bid financial model has the following specifications: a debt-to-equity ratio of 61:39, with 65\% of total debt in hard currency (USD), which accounts for $40 \%$ of total funding (debt and equity). The total project cost of $\$ 300$ million, and the country is below investment grade at BB- on S\&P's rating. The remainder of the debt consists of local currency lending from a state-owned financial institution (30\%) and approximately (5\%) from local commercial lenders. This project was chosen because the specifications represent a typical financial structure for which a guarantee may need to be provided in ADB's DMCs including a high amount of equity relative to developed markets and mixed financing in local and hard currency. The partial risk guarantee provided by MDBs is estimated to reduce the cost of debt by 125 basis points for the hard currency portion of lending. In a financial model, this result will increase the project's equity internal rate of return. This is not realistic as bidders would not require a higher return for a project that has a reduced cost of debt. Therefore, instead of increasing the project's equity internal rate of return, government annuity payments are adjusted downward, assuming the same rate of return and reflecting the reduced cost of funding. This is illustrated in Figure 5.

Figure 5: Government Annuity Payments with and without Multilateral Development Bank Sovereign Partial Risk Guarantees

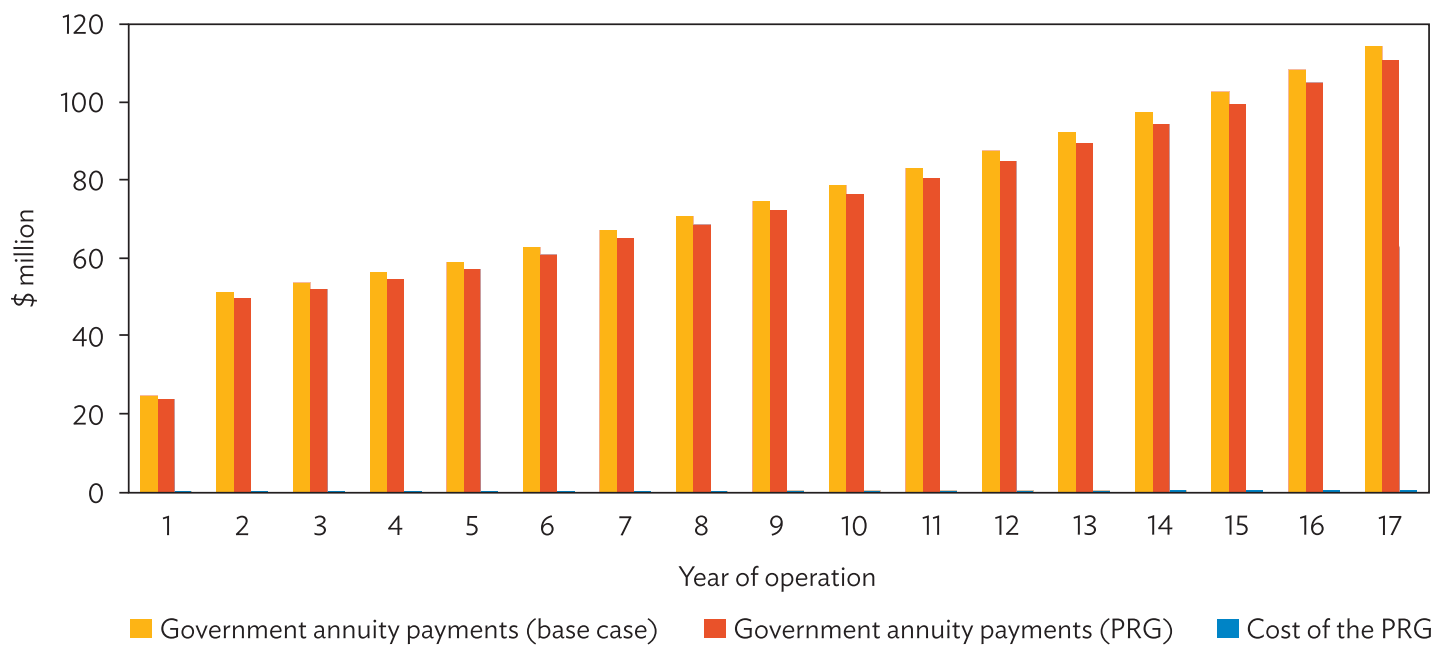

PRG = partial risk guarantee.

Source: Author's calculations. 
Clearly, there is an effective reduction in government annuity payments. The payments are higher under the base-case scenario relative to an MDB's partial risk guarantee. The reduction totaled $\$ 40$ million, but it is associated with a total cost of the sovereign partial risk guarantee amounting to $\$ 7.2$ million during the years of operation (Figure 6). This cost is calculated based on ADB's published figures of a guarantee fee of 50 basis points and a commitment fee of 15 basis points. Thus, under the guarantee terms, a government could save $\$ 32.8$ million (approximately $13 \%$ of the capital expenditure) from a project, which could lead to increased social benefits by allocating these savings to equally important public services. This example is illustrative and real savings could only be demonstrated by actually seeing the results of tendering.

\section{Figure 6: Estimated Financial Benefits of a Sovereign Partial Risk Guarantee}

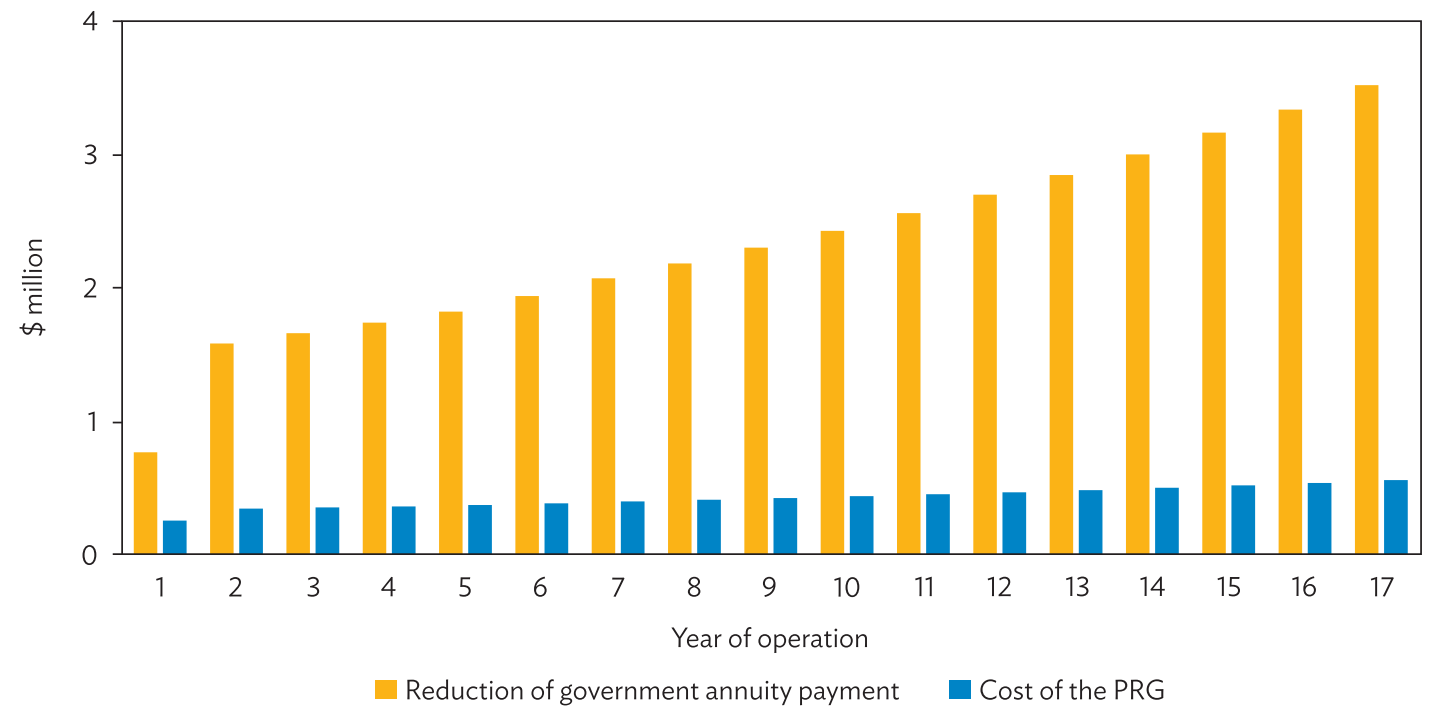

PRG = partial risk guarantee

Source: Author's calculations.

It is important to note that the estimated financial benefits fully accrue to the government only if a partial risk guarantee is made available before bidding. This could be done through a letter of interest or as a stapled financing package offered by MDBs. This allow bidders to adjust their bids according to a project's reduced risk profile. When these guarantees come after the bidding, the financial benefits accrue largely to sponsors and lenders. The government, however, still benefits since this increases the likelihood of a project reaching financial close.

If a PPP project has a partial risk guarantee by an MDB but is not backed by a sovereign counter indemnity, the total cost of the guarantee for the years of operation would be higher at $\$ 18.2$ million (Figure 7). In this case, the financial benefits from credit enhancement by an MDB tend to be lower, at $\$ 21.8$ million or approximately $8 \%$ of capital expenditure. But because many governments are not willing to offer sovereign counter indemnity, the net financial benefits of nonsovereign partial risk guarantees should be considered. 


\section{Figure 7: Estimated Financial Benefits of a Nonsovereign Partial Risk Guarantee}

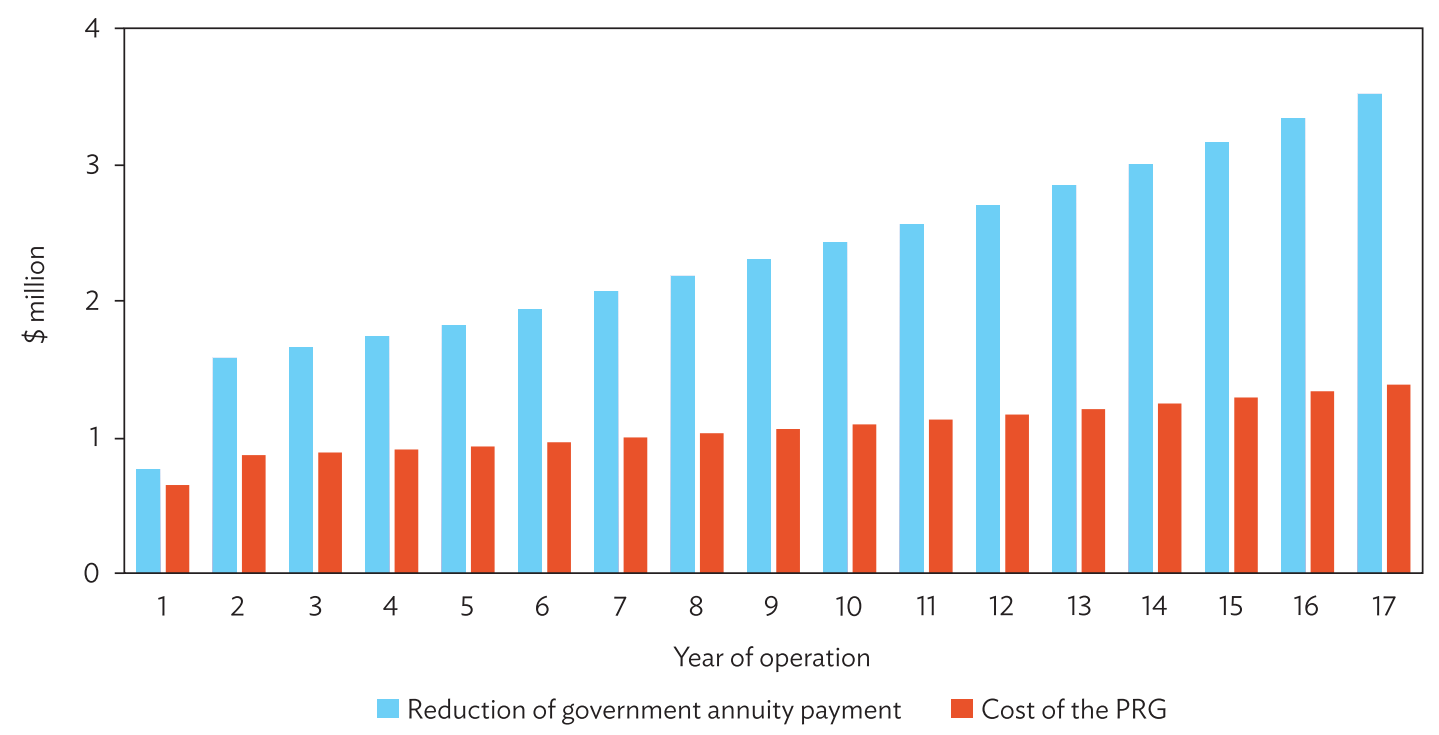

PRG = partial risk guarantee.

Source: Author's calculations.

In practice, the net financial benefits are expected to be larger than the examples presented. First, the model only considers effects that are certain. In the scenarios, debt will be reduced by an MDB guarantee, and a sponsor, after receiving a guarantee, would at the very least demand a similar investment return. In reality, sponsors tend to bid more aggressively, thereby reducing their return in proportion to the reduction in risk. Second, the model assumes a constant debt-to-equity ratio. The level of debt is expected to increase as debt providers could cover a higher percentage of debt. A higher leverage would lower project costs for governments because debt is cheaper than equity. These effects would further reduce the government annuity payment. It should be noted that in some countries, the amount of equity is mandated by law or regulation, which means the second argument would not apply.

\section{CONCLUSION AND POLICY IMPLICATIONS}

Sovereign risk mitigation is often needed to catalyze PPPs in developing economies with high credit risk ratings. In developing Asia, a large percentage of countries borrowing from MDBs are considered risky. Sovereign risk and country risk are associated with the financial closure of infrastructure PPP projects. Reducing these risks through guarantees provided by MDBs is a solution, but this is only one of many options that include private insurance and letters of credit. The case studies from Kenya and Turkey show that in projects with a dedicated source of revenue, and high demand for services, credit enhancement from MDBs helped to enable financial close.

Key risks for private investors include dealing with the government counterparty's payment timeliness and its willingness to pay. Risk mitigation instruments such as MDB-issued letters of credit and partial risk guarantees that are not affected by a country's macro environment are beneficial, and, in some cases, they can raise the credit rating of the project above the sovereign ceiling. The Elaziğ Hospital PPP showed that proper risk mitigation can be used outside of traditional sectors, such as 
power, and are also effective in social sectors. Furthermore, upstream support to Turkey's health sector by the EBRD was considered a material factor determining the project's credit rating. This implies that MDBs should continue their engagement in upstream capacity building since this can have a material impact on PPP investments downstream.

Another policy implication is that there are ways to reduce risk that should be taken before turning to credit enhancement. These include improving domestic investment conditions through increased transparency, practicing risk allocation, and using government support where needed. When credit enhancement is used by MDBs, our empirical analysis shows it can be a significant factor in attracting investment (Appendix). But for the financial benefits of these interventions to accrue to the government, they must be in place before bidding. This implies that there should be an early dialogue between government and MDBs during the transaction advisory stage. 


\section{APPENDIX: ANALYTICAL FRAMEWORK}

This paper ran a panel regression model to explore the effect of the Organisation for Economic Co-operation and Development's (OECD) country risk classifications and Standard \& Poor's (S\&P) sovereign ratings on the number of financially closed infrastructure public-private partnerships (PPPs). The PPP projects are taken from the World Bank's Private Participation in Infrastructure Database and complemented with data from the World Development Indicators with variables such as gross domestic product (GDP), GDP growth, inflation, and country openness. ${ }^{5}$

Following Araya, Schwartz, and Andrés (2013), a Poisson regression model was used.

$$
\begin{gathered}
\ln \left(\lambda_{i}\right)=\beta_{0}+\beta_{1} \text { Risk }_{\text {measures }}+\beta_{2} \text { GDP growth } \\
\beta_{3} \text { Openness }_{i t-1}+\varepsilon_{i t}
\end{gathered}
$$

where $\lambda_{i}$ is the number of projects in country $i$ from 1991 to 2015. Risk measures $i$ are the OECD's country risk classification or S\&P's sovereign ratings. Most econometric specifications dealing with GDP and investments suffer from endogeneity. This is addressed by assuming the investments are being affected by previous-year events. GDP growth $h_{i t-1}$ is GDP growth and is expected to have a positive impact on investments in PPPs. Inflation It $-1_{\text {captures the monetary instability for country } i \text { in }}$ the year $t-1$ and is expected to have a negative impact. Opennes it-1 $_{1}$ is a proxy for the openness of the country calculated as the sum of exports and imports over the GDP; it is expected to have a positive impact on the investments. Inflation and openness are log transformed.

To test the participation of multilateral development banks (MDBs) in catalyzing the private financing of infrastructure projects through various schemes, including credit enhancement products. We introduced a dummy variable 1 if the MDB participates in any of the PPP projects of a given country from 1991 to 2015 or 0, otherwise. The interaction variable between MDBs' PPP participation and OECD's credit risk and S\&P's rating were introduced in the model.

5 The database gives detailed information by year, country, sector, and form of PPP projects that have come to financial closure. Within sectoral categories, it distinguishes among primary and secondary sectors by investment. It also provides the form of private investments, so that greenfield projects and brownfield projects can be distinguished from concessions of existing assets among other types of partnerships and investments. 


\section{REFERENCES}

Araya Gonzalo, Jordan Schwartz, and Luis Andrés. 2013. "The Effects of Country Risk and Conflict on Infrastructure PPPs." World Bank Policy Research Working Paper 6569. Washington, DC: World Bank.

Asian Development Bank (ADB). 2011. Guarantees against Political Risks. Manila.

2017. Public-Private Partnership Monitor. Manila.

Babatunde, Solomon Olusola, and Srinath Perera. 2017. "Barriers to Bond Financing for Public-Private Partnership Infrastructure Projects in Emerging Markets: A Case of Nigeria." Journal of Financing Management of Property and Construction. 22 (1): 2-19.

European Investment Bank (EIB). 2012. An Outline Guide to Project Bonds Credit Enhancement and the Project Bond Initiative. Luxembourg.

Government of Kenya and International Development Association. 2012. Indemnity Agreement: Partial Risk Guarantee in Support of the Kenya Private Sector Power Generation Support Project: Thika Power Project. August.

Hammami, Mona, Jean-François Ruhashyankiko, and Etienne B. Yehoue. 2006. "Determinants of Public-Private Partnerships in Infrastructure.” IMF Working Paper No 06/99. Washington, DC: International Monetary Fund.

Independent Evaluation Department (IED). 2017. Boosting ADB's Mobilization Capacity: The Role of Credit Enhancement Products. Manila: ADB.

International Institute for Sustainable Development (IISD). 2015. "Risk Allocation in Public-Private Partnerships: Maximizing Value for Money.” IISD Discussion Paper. Winnipeg.

Irwin, Timothy. 2007. Government Guarantees: Allocating and Valuing Risk in Privately Financed Infrastructure Projects. Washington, DC: World Bank.

Kaçaniku, Teuta, and Karina Izaguirre-Bradley. 2015. "Kenya: First Commercial Financing for Power Plants Made Possible through a Series of IDA Guarantees." Live Wire 2015/47. Washington, DC: World Bank.

Matsukawa, Tomoko, and Odo Habeck. 2007. "Review of Risk Mitigation Instruments for Infrastructure Financing and Recent Trends and Developments." Trends and Policy Options 4. Washington, DC: World Bank.

Moody's Investors Service. 2016. ELZ Finance SA Presale Report: Elaziğ Hospital PPP Exceeds Turkey's Sovereign Rating with Strong Multilateral Support.

2017. "Credit enhancements from Multilaterals Will Help to Address the Infrastructure Gap." https://www.researchpool.com/provider/moodys-investors-service/global-infrastructurefocus-october-2017. 
$18 \mid$ References

Organisation for Economic Co-operation and Development (OECD). 2017. Selected Good Practices for Risk Allocation and Mitigation in Infrastructure in APEC. Paris.

Schwartz, Jordan Z., Fernanda Ruiz-Nuñez, and Jeff Chelsky. 2014. Closing the Infrastructure Finance Gap: Addressing Risk. Sydney: Reserve Bank of Australia.

Standard \& Poor's Global Ratings. 2017. Sovereign Risk Indicators 2017 Estimates. https://www.sprating.com/sri/.

World Bank. Guarantees Program. http://www.worldbank.org/en/programs/guarantees-program\#5. 


\section{Risk Mitigation and Sovereign Guarantees for Public-Private Partnerships in Developing Economies}

Private investors are concerned about the creditworthiness of public-private partnership (PPP) projects in Asia because a large percentage of developing countries are considered risky counter parties. This paper examines the application of credit enhancement, such as letters of credit and partial risk guarantees, and attempts to quantify the benefits of these instruments. It presents the main risks of infrastructure investors in Asia, the severity of which vary by specific project conditions, and the complementary roles of governments and multilateral development banks in mitigating these risks.

\section{About the Asian Development Bank}

ADB is committed to achieving a prosperous, inclusive, resilient, and sustainable Asia and the Pacific, while sustaining its efforts to eradicate extreme poverty. Established in 1966, it is owned by 67 members48 from the region. Its main instruments for helping its developing member countries are policy dialogue, loans, equity investments, guarantees, grants, and technical assistance. 